\title{
Evaluation of the snow regime in dynamic vegetation land surface models using field measurements
}

\author{
E. Kantzas ${ }^{1}$, S. Quegan ${ }^{1}$, M. Lomas ${ }^{1}$, and E. Zakharova ${ }^{2}$ \\ ${ }^{1}$ Centre for Terrestrial Carbon Dynamics: National Centre for Earth Observation, University of Sheffield, Hicks Building, \\ Hounsfield Rd, Sheffield S37RH, UK \\ ${ }^{2}$ Centre Nationale de la Recherche Scientifique (CNRS), Laboratoire d'etudes en Geophysique et Oceanographie Spatiales \\ (LEGOS), UMR5566 (CNRS, CNES, IRD, Universite Paul Sabatier Toulouse III), 14, avenue Edouard Belin, \\ 31400 Toulouse, France
}

Correspondence to: E. Kantzas (e.kantzas@sheffield.ac.uk)

Received: 25 September 2013 - Published in The Cryosphere Discuss.: 17 October 2013

Revised: 9 January 2014 - Accepted: 14 January 2014 - Published: 24 March 2014

\begin{abstract}
An increasing number of studies have demonstrated significant climatic and ecological changes occurring in the northern latitudes over the past decades. As coupled Earth-system models attempt to describe and simulate the dynamics and complex feedbacks of the Arctic environment, it is important to reduce their uncertainties in short-term predictions by improving the description of both system processes and its initial state. This study focuses on snow-related variables and makes extensive use of a historical data set (1966-1996) of field snow measurements acquired across the extent of the former Soviet Union to evaluate a range of simulated snow metrics produced by several land surface models, most of them embedded in IPCC-standard climate models. We reveal model-specific failings in simulating snowpack properties such as magnitude, inter-annual variability, timings of snow water equivalent and evolution of snow density. We develop novel and model-independent methodologies that use the field snow measurements to extract the values of fresh snow density and snowpack sublimation, and exploit them to assess model outputs. By directly forcing the surface heat exchange formulation of a land surface model with field data on snow depth and snow density, we evaluate how inaccuracies in simulating snow metrics affect soil temperature, thaw depth and soil carbon decomposition. We also show how field data can be assimilated into models using optimization techniques in order to identify model defects and improve model performance.
\end{abstract}

\section{Introduction}

Although data covering the last 125 years indicate no significant surface air temperature trends in the Arctic (Polyakov et al., 2002), warming is observed in recent decades (Serreze et al., 2000), and there are many associated indicators of change, such as the expansion of shrub cover (Sturm et al., 2001), decrease in Arctic sea ice extent (Stroeve et al., 2007, 2012), reduction in spring snow cover (Derksen and Brown, 2012) and warming of permafrost (Osterkamp, 2007). Model projections suggest that Arctic surface air temperatures will increase by as much as $0.25-0.75^{\circ} \mathrm{C}$ per decade over the next 100 years (Serreze and Francis, 2006), with associated increases in precipitation (Christensen et al., 2007). Since these regions hold a third of the global terrestrial carbon (McGuire et al., 1995) and half of the global below-ground organic carbon (Tarnocai et al., 2009), most of it locked in permafrost soils, the importance of recording, monitoring and understanding the complex dynamics and feedbacks of the Arctic climate is evident.

Land, ocean, atmospheric or coupled earth models can offer insights into the multi-level interactions within the system, provided they include and adequately describe the important processes involved. However, significant differences are found in the projections of change made by different models (Friedlingstein et al., 2006). Lack of knowledge of the initial state of the system has been identified as a major cause of uncertainty in decadal projections from climate models (Cox and Stephenson, 2007). This has motivated a 
major effort to compile data sets of essential climate variables (ECVs) from field and Earth observation (EO) data, following the guidelines of the Global Climate Observing System (GCOS, 2004, 2010).

This study focuses on land surface models and their ability to simulate snow-related variables and processes, which play a prominent role at high latitudes. Changes in albedo associated with the reduced extent of spring snow cover in the Northern Hemisphere over the past 20 years have affected the radiative balance and help explain why the long-term (20th century) increase in surface air temperature over Northern Hemisphere land has been greater in spring than in any other season relative to the inter-annual variability (Groisman et al., 1994). Snow is also a hydrological storage pool, collecting precipitation throughout the winter which is then released during the spring, and is essential for local ecosystems and populations. The high latent heat required to melt snow provides a significant cooling effect affecting atmospheric circulation (Vernekar et al., 1995). In addition, the thermal properties of the snowpack make it an efficient insulator, acting as a key control during winter on the heat transfer between the carbonaceous boreal soils and the ambient air, thus affecting permafrost dynamics and soil carbon decomposition. Realistic representation of the snowpack is therefore essential if a land surface model is to provide an accurate and complete formulation of the water cycle and energy flows at high latitudes.

After a description of the data sets and models in Sect. 2, Sect. 3 shows how a range of snow properties (snow water equivalent, snow density and depth, and snowpack sublimation) can be estimated from field data at scales suitable for comparison with land surface models. In Sect. 4, these derived variables are used to assess whether several stateof-the-art land surface models, some of them embedded in IPCC-standard climate models, correctly describe and quantify the snow regime in the Arctic and boreal latitudes. The discussion in Sect. 5 deals with two issues: we firstly investigate how the observed inaccuracies in modelled snow variables affect simulated soil temperatures, and consequently permafrost extent and heterotrophic respiration produced by a land surface model; secondly, we describe how field data can readily be used to optimize model parameters in order to improve its simulation of snow dynamics.

\section{Description of data sets}

\subsection{Field data}

This study uses the Former Soviet Union (FSU) Hydrological Snow Surveys data set (Krenke, 2004), which consists of snow measurements carried out from 1966 to 1996 in the proximity of 1345 World Meteorological Organization (WMO) stations spread throughout the FSU (Fig. 1). The number of stations in the data set reduced from 1345 in 1990

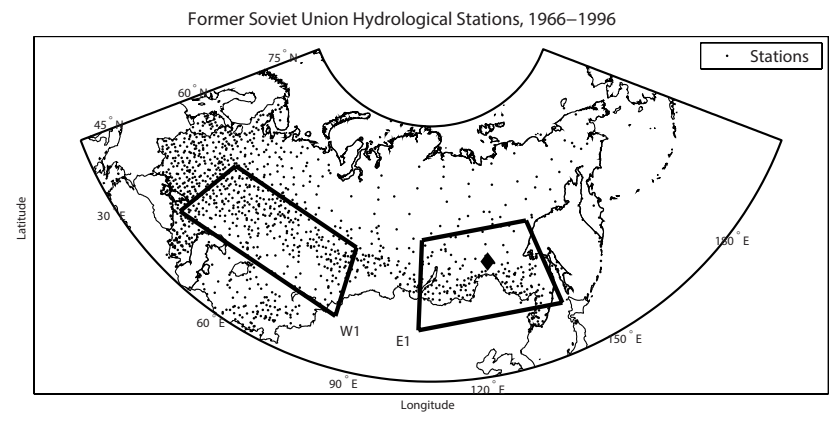

Fig. 1. Location of hydrological stations considered in this study; note the scarcity over northern Siberia. The limits of the western (W1) and eastern (E1) geographical subsets used in Sect. 4.4 are indicated by the rectangles. The diamond marker in E1 indicates the position of the Mogot Basin $\left(55.5^{\circ} \mathrm{N}, 124.7^{\circ} \mathrm{E}\right)$.

to about 200 in 1991, the majority of them located in the European sector of the FSU, with very little coverage over northern Siberia. Each station exhibits different and varying sampling frequency, but measurements were usually taken every 5 or 10 days. Three products are provided. The most detailed is the synoptic product, which contains records of transect measurements made in the vicinity of the stations. Several variables were recorded, of which the most important for this study were snow depth, snow density and snow course type (field, forest, gully or unknown), with field and forest types being the most frequent. The transect product contains the measurements from the synoptic product (with snow water equivalent in place of snow density) that occurred during the three most common days of measurements (the 10th, 20th and final day of each month), so these data are standardized to a common time frame and hence are easier to handle than the synoptic product. Finally, the station product contains the mean snow depth records for the first 10 days, the second 10 days and the remaining days of the month at the locations of the weather stations.

\subsection{Earth observation data}

GlobSnow v.1.3 (Luojus et al., 2011) is a monthly snow water equivalent (SWE) data set covering the period 19792010. Its novel algorithm (Pulliainen, 2006) uses forward modelling of brightness temperatures from three satellitebased radiometers (Nimbus-7 SMMR (1979-1996), DMSP SSM/I (1987-2002) and Aqua AMSR-E (for 2002-2010)) and assimilates field data on snow, including the field data used in this study, to produce a global SWE product. Its accuracy has been demonstrated, and it has been used to estimate trends of SWE over the last 30 years (Takala et al., 2011). Hancock et al. (2013a) further show that, amongst a suite of Earth observation SWE products, GlobSnow offers the highest accuracy due to its assimilation of ground data, thus making it most suitable for testing land surface models. 
The LEGOS SWE retrievals are based on a dynamic algorithm (Mognard and Josberger, 2002) that calculates the snow depth from the spectral gradient of SSM/I brightness temperatures, with additional inputs of air-snow interface temperatures from the National Centers for Environmental Prediction (NCEP) global reanalysis (Kalnay et al., 1996) and snow-ground interface temperatures and snow density derived from the Interactions between Soil, Biosphere, and Atmosphere (ISBA) model (Boone et al., 2006).

\subsection{Land surface models}

Four state-of-the-art land surface models were evaluated, some of which have been coupled to general circulation models used to investigate the land-atmosphere-ocean carbon exchange. CLM4CN (Lawrence et al., 2011) is an updated version of CLM4 with a carbon-nitrogen biochemical model and constitutes the land component in the Community Earth System Model (CESM) (Collins et al., 2006). CLM4CN incorporates the Snow, Ice, and Aerosol Radiation (SNICAR) model (Flanner et al., 2007) to determine snow albedo, while the properties of the snowpack, such as density, evolve due to compaction. CLM4CN includes boreal plant functional types (PFTs) and has specific parameterizations for the thermal and hydraulic properties of organic soil (Lawrence and Slater, 2008); its soil temperature profiles and permafrost distribution compare favourably with observations (Lawrence et al., 2008).

JULES (Best et al., 2011) is the land surface component of the Hadley Centre climate models and is based on the Met Office Surface Exchange Scheme (MOSES) (Essery and Clark, 2003). JULES does not include important parameterizations for northern latitudes, such as organic soils or endemic PFTs, but contains a complex snowpack sub-model with varying snow density, sublimation and snow interception by the canopy (Best, 2009); these processes are also present in CLM4CN.

LPJ-WM (Wania et al., 2009a) is a version of LPJ tailored to northern latitudes by including boreal-specific PFTs and incorporating peatland hydrology, organic soils and permafrost dynamics. The original hydrology (Gerten et al., 2004) was modified to allow more soil layers, while permafrost extent and active layer depth are obtained by modelling the soil temperature profile as a function of depth using a one-dimensional energy flow formulation. However, its representation of snow properties is very simple, with snow density being held constant for the first three quarters of the snow season and increased as a linear function of time during the last quarter, following findings by Oelke et al. (2003) and Ling and Zhang (2004). It does not include canopy interception, sublimation or any of the snow metamorphic processes found in CLM4CN and JULES.

The Sheffield Dynamic Global Vegetation Model (SDGVM) (Woodward and Lomas, 2004; Woodward et al., 1995) has been extensively used in dynamic vegetation model (DVM) comparison studies (Cramer et al., 2001; Le Quere et al., 2009; Piao et al., 2009), and produces magnitudes and trends of carbon fluxes similar to those from other DVMs at global and regional scales. However, it lacks the complexity and many of the processes found in both CLM4CN and JULES: for example, it does not consider the thermal properties of soil, a key drawback when considering permafrost soils at boreal latitudes; has no specific adaptations for northern latitudes; and does not simulate snow interception by the canopy. Nevertheless, it includes sublimation, thus providing a more realistic and complete water balance than LPJ-WM. It is also an in-house model that can be readily modified, and thus is particularly valuable in the optimization of sublimation discussed in Sect. 5.2.

Spatial resolution varies between the data sets and models. GlobSnow data are provided at $25 \mathrm{~km}$ resolution and were converted to $1^{\circ}$ spacing to match the LEGOS SWE product, while the grid-cell spacing of the models is defined by their climate drivers. LPJ-WM is driven by the CRU TS 3.0 (Climate Research Unit Time Series) (Mitchell and Jones, 2005 ) with $0.5^{\circ}$ grid cells, and JULES by WATCH (Water \& Global Change) (Harding and Warnaars, 2011), also at $0.5^{\circ}$. SDGVM is driven by CRU TS 3.0, but at $1^{\circ}$ grid spacing, while CLM4CN uses the CRU+NCEP climatology, based on CRU 2.0 and the NCEP reanalysis (Kanamitsu et al., 2002) at $0.9375^{\circ} \times 1.25^{\circ}$. All model outputs are given as averaged monthly values.

\section{Methods}

In this section we describe the methods used to derive five snow variables from the transect data:

1. Snow water equivalent

2. Fresh snow density

3. Snow density evolution (monthly and daily time steps)

4. Snow depth

5. Snowpack sublimation

The details of how these variables are estimated are in part motivated by the need to compare them with values calculated in models, as will be discussed in Sect. 4.

\subsection{Snow water equivalent}

Monthly averaged SWE outputs were acquired from the lowresolution transect product. Usually, and depending on the spatial resolution of the data set, more than one station falls within the spatial extent of each grid cell. Since the cover type for each station was provided, this allowed the SWE for forest and non-forest areas to be estimated. The SWE 
for the whole grid cell was then calculated as the weighted average of these two values, where the weights were given by the fractions of the grid cell covered by forest and nonforest. These fractions were derived from the MODIS Vegetation Continuous Fields (MODIS VCF) MOD44B land cover product (Hansen et al., 2003). A similar approach was applied for the other snow variables described in later subsections.

\subsection{Snow density}

The thermal conductivity of the snowpack increases with snow density (Saito et al., 2012; Sturm, 1992, 1997), making this variable important for the energy balance of the soil column. Since its conductivity tends to be small, the snowpack acts as a thermal insulator and reduces the magnitude of fluctuations in temperature and heat propagating from the air to the soil. Snow density also has a small effect on the radiation balance because of its effects on albedo (Bohren and Beschta, 1979), but the grain size is more important (Perovich, 2007). Estimating snow density requires both the initial value for fresh snow (Sect. 3.2.1) and a procedure to track its development up to melting (Sect. 3.2.2).

\subsubsection{Fresh snow density}

The density of fresh snow provides the starting point for snow evolution, and so is an important property of the snowpack, especially early in the snow season. In order to estimate a value of fresh snow density applicable mainly to the beginning of the snow season, we scanned the entire synoptic data set, approximately 600000 measurements, for pairs of measurements that were taken less than $N$ days apart, in which the earlier record showed no snow but the latter had positive values of snow depth. It was then assumed that the age of the snow would be uniformly distributed on the interval $[0, N]$ days, with an expected value of $N / 2$ days, and so the latter record represented the value of fresh snow density $N / 2$ days after the initial snowfall. This is less likely to be correct as $N$ increases, because snow undergoes densification immediately following its deposition, while newly deposited snow can dilute the snowpack and decrease its overall density. To reduce the effect of such perturbations, only measurements acquired up to $N=3$ days apart were considered. This was possible because, although most of the records in the synoptic data set were collected with a 5- or 10-day step, there were 60 pairs of measurements at the beginning of the snow season taken less than 4 days apart in which the earlier had a snow depth of zero and the later a positive value.

To optimize the algorithm two restrictions were applied. As the transect measurements used in this retrieval would involve newly deposited and therefore shallow snowpacks, transects carried out in forests were not considered, in order to avoid potential perturbations caused by the heterogeneity of a shallow forest snowpack. Additionally, the Global
Summary of the Day (GSOD) (NCDC, 2013) data set was used to identify the minimum air temperature $\left(T_{\min }\right)$ for the station location on the day of the transect; since fresh snow density is a function of air temperature (Anderson, 1976) and what is sought here is an estimate for the early stages of the snow season, any values acquired when $T_{\min }<-10^{\circ} \mathrm{C}$ were filtered out. Consequently, the fresh snow density produced by the retrieval will be more suitable for snowfalls at relatively warmer temperatures, just below $0^{\circ} \mathrm{C}$, usually prevailing during the beginning and end of the snow season.

\subsubsection{Snow density evolution (monthly time step)}

After deposition, overburden pressure and prevailing weather conditions, such as temperature and wind, cause continual evolution of the snowpack density (Anderson, 1976; Liston and Elder, 2006), with a tendency for increases over the winter period, reaching a maximum before or during melt. Using the same approach as for SWE, monthly values of density were estimated using the transect product as a weighted average of values for forest and non-forest areas.

\subsection{Snow depth and density (daily time step)}

Daily time series for both snow depth and density had to be created from the data records for exploitation by LPJ-WM in the permafrost analysis in Sect. 5.1. Only stations overlying organic soils which had nearly complete temporal coverage with few data gaps were selected in order to ensure a more accurate construction of daily time series. This led to a data set containing nine stations, all located either in south-central Eurasia, where the permafrost boundary lies, or eastern Eurasia, where low air temperatures contribute to predominantly continuous permafrost; there were none in the western sector, where permafrost is generally absent.

The station data set contains records of mean snow depth at the location of each station for the first 10 days, the second 10 days and the remaining days of the month, while the transect data set contains records of snow depth and snow density on the same days, but acquired along transects in the vicinity of the station. In the former, snow depth was assigned a zero value when snow was absent, so no gaps occur, even during the summer and spring. In contrast, the transect measurements took place only when snow was present; in its absence, the records contain no data, limiting our ability to detect the start and end dates of the snow season. Hence we utilized both sets, acquiring snow depth from the station records and snow density from the transect records, after first ensuring that the snow depth for each station from the two data sets was well correlated $(\rho \geq 0.9)$ and had the same mean.

To form daily snow depth fields between the 10-day interval of the station records, an increase between two dates was attributed entirely to snowfall on the second date (a step function), while decreases were calculated using linear interpolation between observed values. Snow density was linearly 
interpolated when it was both increasing and decreasing, but a lower limit of $100 \mathrm{~kg} \mathrm{~m}^{-3}$ was imposed during the early part of the snow season, and at the end of the season it was assigned the value of the last available record before snow depth reached zero.

\subsection{Snowpack sublimation}

The snow mass balance equation can be written as

$P-S_{\mathrm{S}}-S_{\mathrm{c}}-M-T-T_{\mathrm{S}}=0$,

where $P$ is precipitation (snowfall), $S_{\mathrm{S}}$ and $S_{\mathrm{C}}$ are snowpack and canopy sublimation respectively, $M$ is melt, $T$ is wind transport of snow (blown snow or snow divergence) and $T_{\mathrm{S}}$ is sublimation of the blowing snow. An accurate description of snow dynamics requires knowledge of each of these terms as they all contribute, to a different degree, to the snow mass balance. While the main source term, snowfall $(P)$, can readily be obtained from field measurements, there are inherent difficulties in distinguishing the relative contribution of snow ablation caused by the remaining terms and particular sublimation (Lundberg and Halldin, 2001).

Both $T$ and $T_{\mathrm{S}}$ may become significant terms in the snow mass balance over limited spatial regions and for favourable meteorological conditions, such as during blowing snow events (Pomeroy and Essery, 1999) or at high altitudes (Hood et al., 1999). However, model-based approaches by both Dery and Yau (2002) and Yang et al. (2010) demonstrated how, for the majority of the continental regions of the northern latitudes, wind transport of snow $(T)$ is negligible under coarse resolutions but a significant contributor to snow divergence in coastal regions and the Arctic ocean. For the continental Eurasian region examined in this study, both modelling approaches also yielded very small magnitudes for sublimation of blowing snow $\left(T_{\mathrm{S}}\right)$, although Yang et al. (2010) produced higher values (2-5 mm annually) than Dery and Yau (2002). On the other hand, Brun et al. (2013) showed that simulations of SWE over Eurasia by the ISBA model significantly improve when blowing snow sublimation $\left(T_{\mathrm{S}}\right)$ is considered, although no values for the region were presented. These disparities in model findings, combined with the paucity of field measurements, cast some uncertainty on the relative importance of blowing snow and blowing snow sublimation in the overall snow mass balance.

Available in situ sublimation data $\left(S_{\mathrm{S}}\right.$ and $\left.S_{\mathrm{C}}\right)$ exist but are sparse and of limited spatial extent, with the available information being restricted to point measurements at field sites, usually obtained by a variety of weighting techniques, on-site modelling (Hood et al., 1999), flux towers (Harding and Pomeroy, 1996) and pan methods (Zhang et al., 2005), or any combination of the above (Gelfan et al., 2004). For the overall snow mass balance, both snowpack and canopy sublimation are important, but differences in meteorological conditions and incoming radiation fluxes cause the latter to dominate (Reba et al., 2012; Zhang et al., 2005), espe- cially late in the snow season (Molotch et al., 2007; Lundberg and Halldin, 2001; Pomeroy et al., 1998). The magnitudes of $S_{\mathrm{S}}$ and $S_{\mathrm{C}}$ usually significantly exceed those of $T$ and $T_{\mathrm{S}}$; for continental Eurasia, simulations by both Yang et al. (2010) and Dery and Yau (2002) produced values of snowpack sublimation ranging from 5 to $60 \mathrm{~mm}$ annually, a range which encompasses values usually reported in the literature for field measurements. Here a novel and model-independent approach is presented in which the transect measurements are employed to retrieve values of the monthly snowpack ablation, $A_{\mathrm{S}}$, with melt excluded $\left(A_{\mathrm{S}}=S_{\mathrm{S}}+T+T_{\mathrm{S}}\right)$ in order to provide the basis for evaluating values calculated by models. As the available field data only contain information about the snowpack, intercepted snow is not considered; the retrieved values will therefore include the effects of sublimation, snow transport and blown snow sublimation exclusively from the snowpack, although, based on the literature presented above, sublimation will likely be the major contributor.

Let $\mathrm{SWE}_{\mathrm{A}}$ and $\mathrm{SWE}_{\mathrm{B}}$ be consecutive snow water equivalent measurements from the synoptic transect data set around a particular station on Julian days $T_{\mathrm{A}}$ and $T_{\mathrm{B}}$, with $T_{\mathrm{B}}$ $T_{\mathrm{A}} \leq 10$. An estimate of the monthly ablation, $A_{\mathrm{S}}$, in month $m$ is then provided by

$\mathrm{A}_{\mathrm{S}}=-d(m) \frac{\mathrm{SWE}_{\mathrm{A}}-\mathrm{SWE}_{\mathrm{B}}}{t_{\mathrm{B}}-t_{\mathrm{A}}}$,

where $d(m)$ is the number of days in month $m$. Whenever a pair of records meets the above conditions, a value for $A_{\mathrm{S}}$ is obtained. For each station, the representative monthly value for $A_{S}$ is then taken to be the mean value of all these estimates over the months and years for which data are available. To avoid including precipitation $(P)$ or melt $(M)$ (see Eq. 1) in the calculation of $A_{\mathrm{S}}$, two conditions had to apply between days $T_{\mathrm{A}}$ and $T_{\mathrm{B}}$ :

1. maximum air temperature did not exceed $0{ }^{\circ} \mathrm{C}$, thus excluding melting events;

2. no precipitation occurred, thus excluding snowfall.

None of the snow transect data sets includes such information; it was instead obtained from daily meteorological data compiled from the reports from $600 \mathrm{WMO}$ stations across Russia (Razuvayev et al., 1993) which were cross-referenced with the snow station data. The snow data used constituted the detailed synoptic product, supplemented with additional snow survey data that span from 1966 up to 2012 for a small subset (approx. 515) of synoptic stations (Bulygina et al., 2013).

\section{Results}

In this section we display the values derived by the methods set out in Sect. 3 and compare them with corresponding values calculated by the models. Different formulations of snow 
processes are used by each model, and this is reflected in the models discussed in each subsection.

\subsection{Snow water equivalent comparisons}

Snowpack SWE is calculated by all four models and is also given by the GlobSnow and LEGOS EO products. In order to compare these six data sets with the SWE values derived from the transect data, for every grid cell we defined vectors $\boldsymbol{A}_{\mathrm{k}}, k=1-6$, and $\boldsymbol{B}$, whose elements are the monthly values of SWE for the six data sets and transect measurements respectively. These were used to define two statistics:

i. $\rho_{\mathrm{k}}$, the correlation coefficient between the time series for data set $k$ and the transect data, i.e. between $\boldsymbol{A}_{\mathrm{k}}$ and $\boldsymbol{B}$;

ii. $\Delta_{\mathrm{k}}=\left(\bar{A}_{\mathrm{k}}-\bar{B}\right) / \bar{B}$,

which quantifies the bias in data set $k$ relative to the observed mean SWE, $\bar{B}$; here the overbar denotes average.

All comparisons between models and field records were carried out for the full available temporal range of the transect data (usually 1966-1990 or 1966-1996), while for the EO products the range was restricted to their current availability: GlobSnow from 1980 to 1996 and LEGOS from 1988 to 1996 , but only for latitudes north of $50^{\circ} \mathrm{N}$.

Comparisons between the transect product and the data sets are presented in Fig. 2 for each data set, with the correlation coefficient $\rho$ in the left column and $\Delta$, the relative bias, on the right. The months May to August were excluded and grid cells with less than 30 pairs available for correlation are not shown. GlobSnow achieved the best agreement with the transect data, with over $80 \%$ of the grid cells having a correlation coefficient exceeding 0.6 ; this is expected since the Eurasian data were used in the calibration of GlobSnow. However, a region of low correlation occurs around the southern border of FSU, probably as the higher relief of the area is not accounted for by the retrieval. In contrast, only $54 \%$ of the grid cells had $\rho \geq 0.6$ in the LEGOS EObased SWE product for which data were available only for latitudes north of $50^{\circ} \mathrm{N}$. As has been demonstrated (Foster et al., 1997; Pulliainen, 2006; Takala et al., 2011), temporal and spatial biases in radiometry mean that a single algorithm, like that used by LEGOS, cannot provide accurate and global SWE estimates without assimilating ground data or using forward modelling, as in GlobSnow. The similarities between the LPJ-WM and SDGVM correlation maps can be attributed to their use of the same climate drivers. For these two models, $79 \%$ and $74 \%$ respectively of grid cells have $\rho \geq 0.6$, and, like GlobSnow, both exhibit lower correlation in the south of the FSU. Approximately $78 \%$ of the CLM4CN grid cells have $\rho \geq 0.6$, with poorer correlation in southeastern Siberia, while for JULES $79 \%$ of the grid cells have $\rho \geq 0.6$.

The relative bias, $\Delta$, is shown in Fig. 2 (right) for grid cells with $\rho \geq 0.6$. GlobSnow again agrees well with the data. Fewer grid cells are marked in the LEGOS data set because the correlation is poorer, and SWE is underestimated in most parts of Eurasia. LPJ-WM, SDGVM and CLM4CN all tend to overestimate SWE in the European sector, but perform well elsewhere in terms of both $\rho$ and $\Delta$. In contrast, JULES significantly and systematically underestimates SWE throughout Eurasia, in many regions by more than $50 \%$, despite the high values of the correlation coefficients.

Since all winter months were considered in estimating $\rho$, this is more a measure of seasonal than inter-annual variability: it essentially evaluates how well the data sets capture snow appearance and disappearance dates and the variations of SWE throughout the season. To investigate whether the models reproduce the observed inter-annual variability, correlation coefficients using only the January values were calculated for the available periods of each model. JULES performed notably better than the other models: $63 \%$ of its grid cells had $\rho \geq 0.6$, compared with only $32 \%, 25 \%$ and $13 \%$ respectively for LPJ-WM, SDGVM and CLM4CN.

In the calculations above, all models used their default or "native" climate drivers; these are constructed from data from the same meteorological stations and are thus expected to be similar. Hancock et al. (2013b) argue that differences between JULES estimates and observations could arise from the precipitation data in WATCH, since the use of gauge data to bias-correct reanalysis data is inappropriate for snow. Therefore, to check whether different climate data sets could cause significant differences in SWE, we ran SDGVM with both its default CRU driver and WATCH data, and found very similar results. Hence the fact that the other models produce values of SWE consistent with field data indicates that these models are in some sense tuned to the data or that the underestimation of SWE by JULES is caused by snow process representations within the model itself (note that JULES could not be run with CRU data, since these are monthly values, while JULES requires 6-hourly data, such as those provided by its default WATCH climate data set).

\subsection{Fresh snow density}

The water-to-snow density ratio of fresh snow is often considered to follow the "10:1 rule"; that is, fresh snow has a density of $100 \mathrm{~kg} \mathrm{~m}^{-3}$, although factors such as atmospheric temperature can cause variations (Judson and Doesken, 2000; Roebber et al., 2003). This rule is followed by JULES, but LPJ-WM adopts a snow density of $150 \mathrm{~kg} \mathrm{~m}^{-3}$ for the first three quarters of the snow season, and CLM4CN defines fresh snow density as a function of air temperature according to Anderson (1976), varying from 50 to $170 \mathrm{~kg} \mathrm{~m}^{-3}$. SDGVM does not calculate snow density or snow depth, so is not relevant to this section.

The box plots of Fig. 3 show the mean, median, 25th and 75 th percentiles and range of snow density acquired from a total of 50 pairs of transect measurements for days $N=1$, 2 and 3 following a first snowfall, which, according to the 

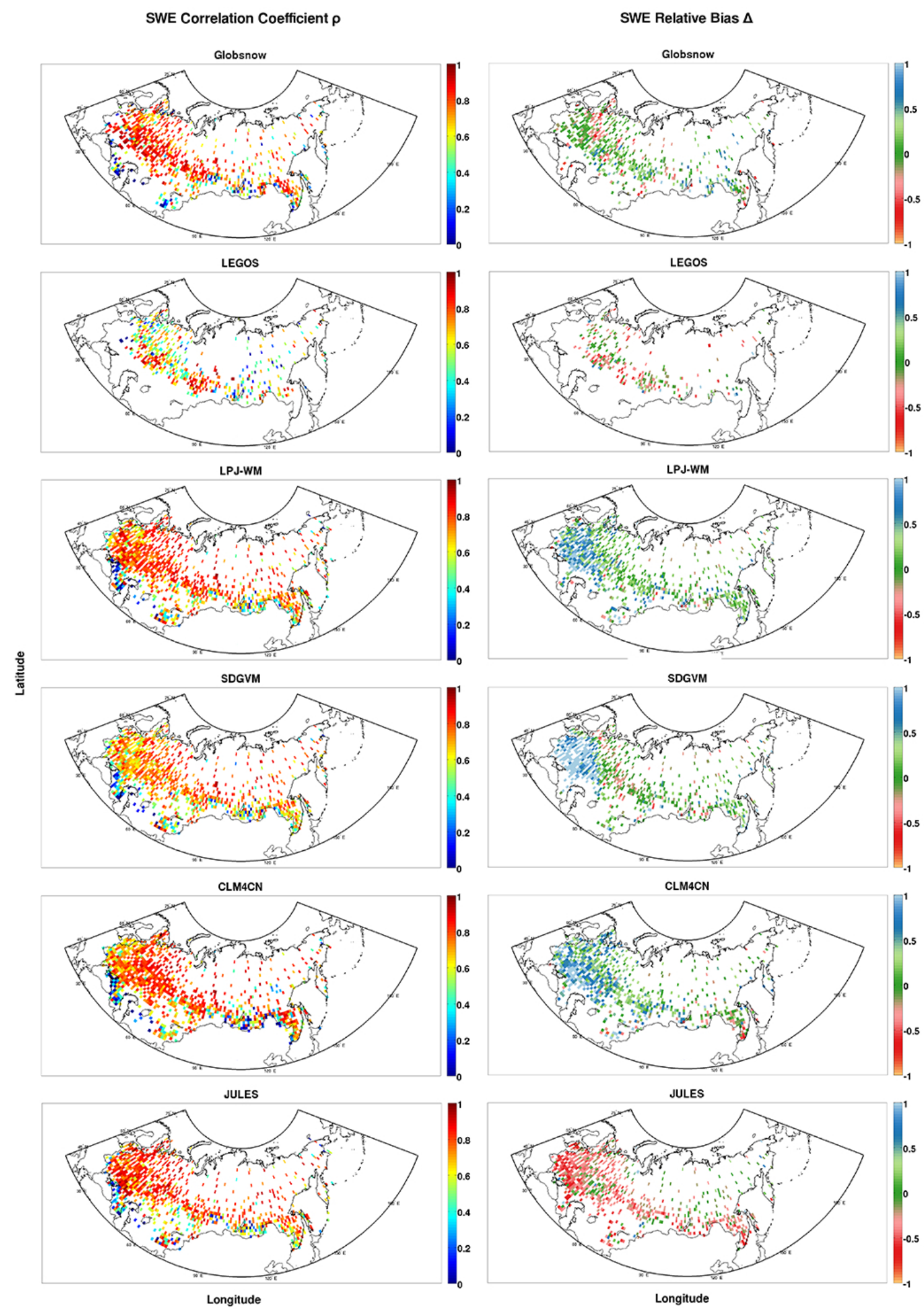

Fig. 2. (left) Correlation coefficient of monthly SWE, $\rho$, between the transect record and the six data sets across the extent of the FSU. (right) Relative bias, $\Delta$, between the transect records and the data sets for grid cells with $\rho \geq 0.6$. 


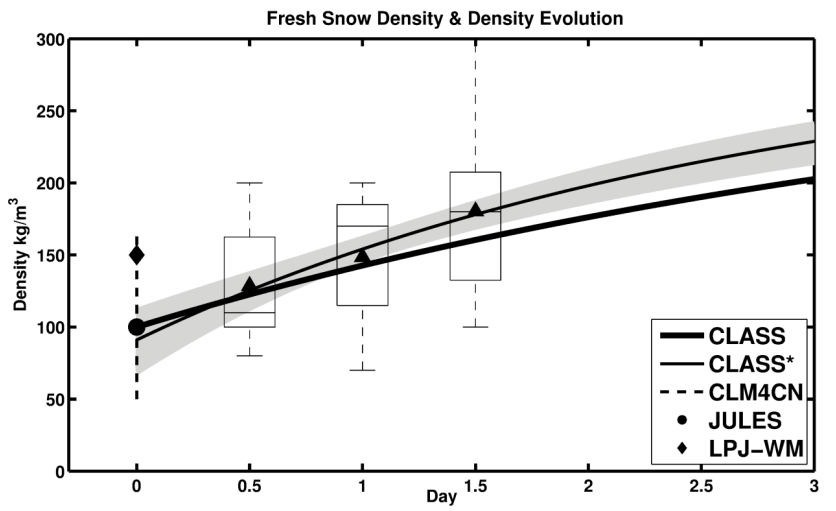

Fig. 3. Fresh snow density $($ day $=0)$ in CLM4CN, JULES and LPJWM as well as snow density evolution in the CLASS model. Box plots show snow density statistics extracted from the transect data with the triangle showing the mean value. CLASS* shows the snow density evolution in the CLASS model but with parameters obtained through regression analysis; the grey area depicts $80 \%$ confidence intervals.

method detailed in Sect. 3.2.1, are taken to represent mean snow age at days $1 / 2,1$ and $3 / 2$ respectively. Fresh snow density and density evolution in a range of models are also shown. The Canadian Land Surface Scheme (CLASS) model (Verseghy et al., 1993) defines snow density evolution as an exponential function of time:

$\rho(t)=\left[\rho_{\mathrm{fr}}-\rho_{\max }\right] e^{-R t}+\rho_{\max }$,

where $R=0.24$ day $^{-1}$ defines the rate of densification; $\rho_{\mathrm{fr}}$ is the fresh snow density and $\rho_{\max }$ the maximum attained snow density, set at $100 \mathrm{~kg} \mathrm{~m}^{-3}$ and $300 \mathrm{~kg} \mathrm{~m}^{-3}$ respectively; and time $t$ is given in days. Later versions of CLASS (Bartlett et al., 2006) use a different algorithm in which both $\rho_{\text {fr }}$ and $\rho_{\max }$ are functions of temperature and snow depth respectively, but the simpler description of snow density evolution in Eq. (4) has the advantage that the parameters can be estimated from the transect data. The best-fit estimates for $\rho_{\mathrm{fr}}$ and $R$ were derived by linear regression after logarithmic transformation of Eq. (4) using the three observed snow density values as realizations of $\rho(t)$ for $t=0.5,1$ and 1.5 while preserving the value of $\rho_{\max }=300 \mathrm{~kg} \mathrm{~m}^{-3}$. The densities derived from the ground data are averages of approximately 20 measurements, and so are expected to be reasonably unbiased and accurate. Hence the principal source of uncertainty in the regression is errors in the time assigned to the snow events, which we are effectively obliged to take as multiples of $1 / 2$ a day. Since these are unlikely to be systematically biased in time about the chosen time points, the regression procedure should not lead to any bias in the estimated parameters.

After reversing the transform, the new representative median values were $\rho_{\mathrm{fr}}=91.0 \mathrm{~kg} \mathrm{~m}^{-3}$ and $R=0.36$ day $^{-1}$; in other words, the densification rate increased but the fresh snow density was reduced. Figure 3 shows the temporal evo- lution of both CLASS, with the original parameters, and CLASS*, whose parameters were derived from the regression. By adopting the snow density evolution of CLASS and utilizing the synoptic data set, regression analysis suggests that, for the spatial coverage offered by the transect data in Eurasia, a value of fresh snow density within the range 68$111 \mathrm{~kg} \mathrm{~m}^{-3}$ (80\% confidence interval for $t=0$ days) is appropriate early in the snow season. This is within the lower half of the range proposed by CLM4CN and includes the $100 \mathrm{~kg} \mathrm{~m}^{-3}$ value used by JULES, but the initial value of $150 \mathrm{~kg} \mathrm{~m}^{-3}$ assumed by LPJ-WM appears too high, probably as a result of compensation for the lack of snow density evolution by the model in the initial 3/4 of the snow season.

\subsection{Snow density evolution}

Monthly values of snow density were extracted from the transect data set and compared with the monthly density obtained by JULES and CLM4CN for each month and each possible grid cell over the period 1966-1996 across the spatial extent of the data; these are the only two models containing processes controlling density.

CLM4CN performs very well in describing the increase of snow density throughout the year $(\rho=0.60)$, as shown in the plot of Fig. 4 (top). When individual months are examined, low correlation is observed in October and the model overestimates snow density in March; both issues can be attributed to inaccuracies in snow timings, since these two months mark the start and end of the snow season for the region. It was indeed found that most of the areas with poor snow density correlation also exhibited poor SWE correlation or overestimation of SWE (Fig. 2). Snow density is affected by overburden pressure, which is taken as proportional to SWE in CLM4CN; hence improved representations of SWE magnitude and timings are likely to improve simulation of snow density evolution.

In contrast, snow density evolution in JULES is characterized by a very slow increase after deposition, especially during October and November. This does not agree with the transect data set and causes JULES to underestimate density throughout the winter (Fig. 4, bottom), perhaps as a result of its underestimation of SWE (Fig. 2). As discussed in Sect. 5.1 , this hinders the ability of JULES to provide accurate simulations of soil temperature.

\subsection{Snowpack sublimation}

Values of monthly mean $A_{\mathrm{S}}$ (1966-2012) acquired from forest transect measurements were generally lower that those obtained from fields, and for both types of cover $A_{\mathrm{S}}$ is largest during the spring months when meteorological conditions (temperature, radiation) favour sublimation. This consistency with expected behaviour supports the validity of the retrieval methodology described in Sect. 3.4. Monthly mean values were considered only when more than 10 measurements of 

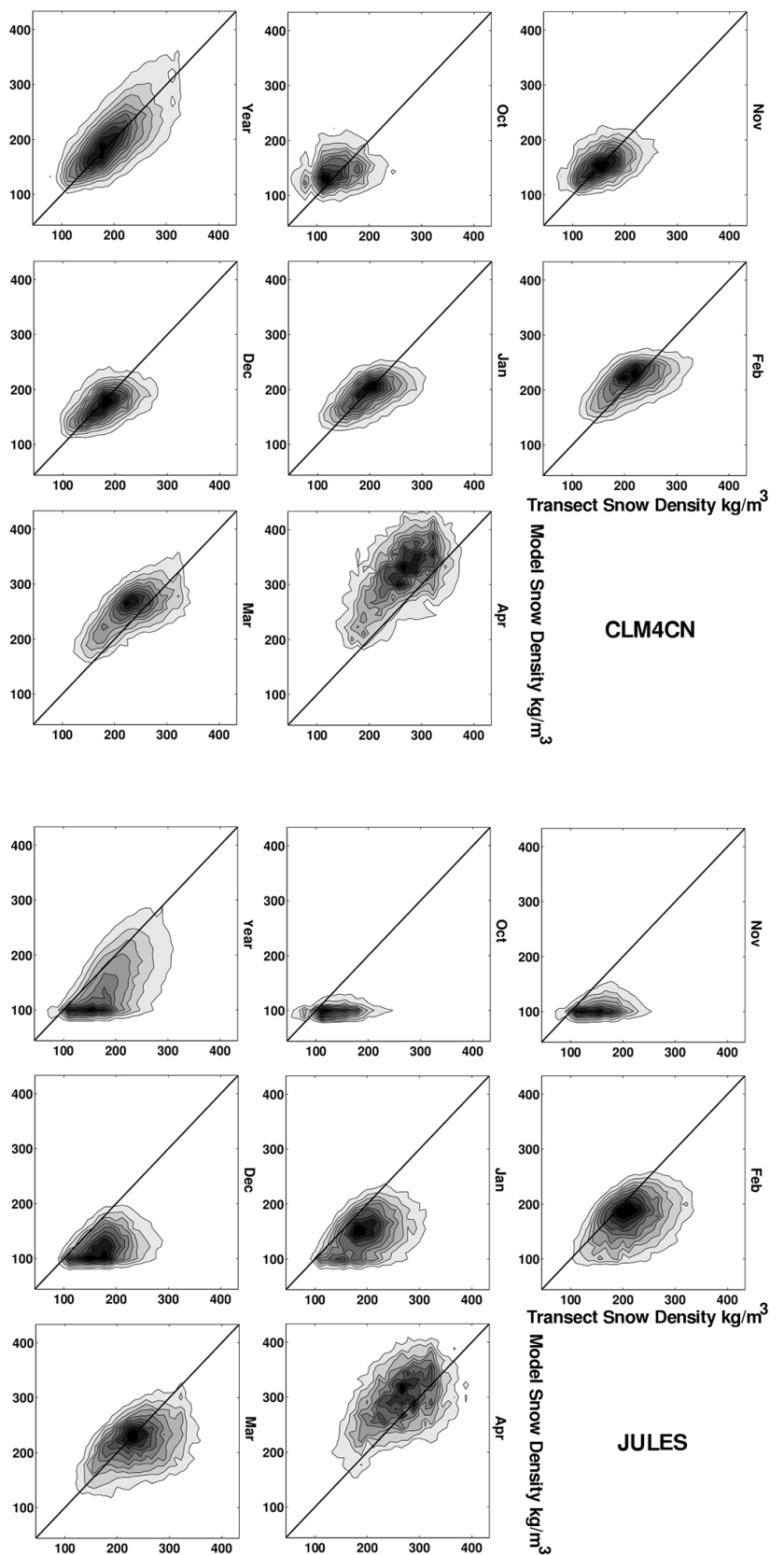

Fig. 4. Density histograms of monthly snow density for CLM4CN (top) and JULES (bottom) compared to the transect data set for the entire snow season (year) and for individual months, across the full spatial and temporal extent of the transect data set.

$A_{\mathrm{S}}$ were available to produce the mean and when the latter exceeded an $80 \%$ confidence interval of having a true value different than zero. These restrictions filter out the vast majority of the measurements; as a result, values of $A_{\mathrm{S}}$ could not be produced for the early months of the snow season and are omitted. The later months of the snow season are better represented, not only because snow was almost guaranteed to be present but also because the sampling frequency of measure-
Table 1. Mean monthly values of $A_{\mathrm{S}}$ averaged over the two subsets of Fig. 1 for field and forest cover. A negative sign indicates snow deposition (condensation); positive indicates removal.

\begin{tabular}{llrr}
\hline Subsets & Cover & Feb & Mar \\
\hline E1 & Field & 2.9 & 8.0 \\
& Forest & -0.3 & 2.9 \\
& Combined & 0.8 & 4.6 \\
\hline W1 & Field & 1.8 & $7.2^{*}$ \\
\hline * Denotes the lower limit for the period. &
\end{tabular}

ments doubled during that period (from 10 days to 5). The lack of estimates in northern Siberia is due to the scarcity of WMO stations.

Despite the low spatial density of estimates and uncertainties in the size of the contribution of individual processes (sublimation, snow divergence, sublimation of blowing snow) to $A_{\mathrm{S}}$, representative values of $A_{\mathrm{S}}$ could be produced across regions and provide the basis for model evaluation. Ideally, these regions would be selected based on their climatic characteristics, as in Bulygina et al. (2011), but, in practice, availability of data dictates their boundaries. Two geographical subsets were thus considered, a western (W1) and an eastern (E1), the boundaries of which can be seen in Fig. 1.

For field cover and the eastern subset E1, monthly mean values of $A_{\mathrm{S}}$ were calculated as 2.9 and $8.0 \mathrm{~mm}$ for February and March respectively (Table 1). For the western subset W1 and months February and March, the spatially averaged values of $A_{\mathrm{S}}$ for the snowpack were 1.8 and $7.2 \mathrm{~mm}$ respectively; for both regions there was a statistically significant increase of $A_{\mathrm{S}}$ towards the end of the snow season, probably caused by sublimation. Two important comments should be made at this point. As mentioned earlier, the methodology discards measurements from days when the maximum air temperature exceeded $0^{\circ} \mathrm{C}$ to avoid perturbations from melt. This does not cause a problem for the eastern subset, which experiences harsher winters and in which snow disappearance occurs from April to May (Kouraev and Mognard, 2010). However, melting begins for the western subset as early as March; therefore, the March mean value of $A_{\mathrm{S}}$ for the western subset should be treated as a lower limit and potentially could exceed the value for the eastern subset. Additionally, both the VCF land cover product (see Sect. 3.1) and the metadata for the synoptic records indicate that the western sector consists mainly of herbaceous cover $(\approx 90 \%)$, while the eastern sector is a mixture of deciduous forests and herbaceous cover $(\approx 34 \%$ and $66 \%$ respectively). Therefore, while the estimates of $A_{\mathrm{S}}$ for field cover in the western sector can be considered as representative for the region, for the western sector they must be weighed against the estimates of $A_{\mathrm{S}}$ for forest cover (see Table 1, "Combined"). 
There are not sufficient data in the west to derive a representative value of $A_{\mathrm{S}}$ for forest cover, which is located mainly in the north of the region. In the eastern E1 subset, monthly values of $A_{\mathrm{S}}$ in forest for February and March were -0.3 and $2.9 \mathrm{~mm}$ respectively, which is significantly less than the estimates of $A_{\mathrm{S}}$ for field cover in E1 for the same months. The negative sign reveals deposition of snow, especially during February, most likely from condensation, assuming that the magnitude of snow divergence is minimal since it is averaged over a large region.

Only limited independent information is available to assess the values of $A_{\mathrm{S}}$ in Table 1. Zhang et al. (2005) measured snowpack sublimation in the Mogot Basin $\left(55.5^{\circ} \mathrm{N}\right.$, $124.7^{\circ} \mathrm{E}$; shown in Fig. 1) in eastern Siberia in a field and two forest sites, and for the period 13 March-22 April 2002 found snowpack sublimation rates of 15.7, 12.1 and $12.4 \mathrm{~mm}$ respectively. For the closest forest stations where estimates were available (Dzalinda station: $-53.28^{\circ} \mathrm{N}$, $123.54^{\circ} \mathrm{E}$; Tynda station: $\left.-55.11^{\circ} \mathrm{N}, 124.4^{\circ} \mathrm{E}\right)$, the March mean values of $A_{\mathrm{S}}$ were $9.7 \mathrm{~mm}$ and $8.3 \mathrm{~mm}$ respectively, while for three stations with field cover (Skovorodino: $-54.0^{\circ} \mathrm{N}, 123.58^{\circ} \mathrm{E}$; Cernjaevo: $-52.47^{\circ} \mathrm{N}, 126.0^{\circ} \mathrm{E}$; Erofey Pavlovic: $-53.58^{\circ} \mathrm{N}, 121.56^{\circ} \mathrm{E}$ ), estimates of $A_{\mathrm{S}}$ were $6.78,9.6$ and $14.3 \mathrm{~mm}$ respectively. The lower values of our estimates of $A_{\mathrm{S}}$ compared to the field measurements can be attributed to the latter involving not only March but also most of April, when sublimation increases.

For larger geographical subsets, only model simulations provide a source to evaluate values of $A_{\mathrm{S}}$. By comparing adjacent forest and field sites, Zhang et al. (2005) and Reba (2012) showed that snowpack sublimation is smaller in forests, mainly because of lower wind and net radiation, the latter of which is very sensitive to canopy characteristics (Davis et al., 1997). Furthermore, as Dery and Yau (2002) showed, the relative air humidity with respect to ice is lower in western Siberia than the east, so sublimation is likely to be higher in the western sector as it also dominated by field cover. Indeed, for December to February (2006/2007), the modelling in Yang et al. (2010) found overall mass changes ranging from only $1 \mathrm{~mm}$ of sublimation to $5 \mathrm{~mm}$ of condensation for the snowpack (sector E1), while in the west (sector W1) $A_{\mathrm{S}}$ ranged from 10 to $25 \mathrm{~mm}$, mainly due to sublimation. For the same months but a different period, Brun et al. (2013) also found condensation in the eastern subset $(-3.5$ to $-7.5 \mathrm{~mm})$ and sublimation in the west $(3.5$ to $6.5 \mathrm{~mm}$ ). Dery and Yau (2002), using process modelling and the 6-hourly European Centre for Medium-Range Weather Forecasts (ECMWF) reanalysis (ERA15) data set at $2.5^{\circ}$ resolution for 1979 to 1993 (Gibson et al., 1997), published values of $A_{\mathrm{S}}$ that ranged from 5 to $25 \mathrm{~mm} \mathrm{yr}^{-1}$ for eastern and from 50 to $75 \mathrm{~mm} \mathrm{yr}^{-1}$ for western Russia. Although higher than the other modelling approaches, these values represent the entire snow season, so include March and April, when sublimation is expected to be higher. Overall, the modelling results point to (i) a seasonal positive value for $A_{\mathrm{S}}$ in the
Table 2. Simulations of monthly snowpack sublimation (October to April) and total sublimation for the JULES and SDGVM models for the eastern and western Eurasian subsets shown in Fig. 1.

\begin{tabular}{|c|c|c|c|c|c|c|c|c|}
\hline & \multicolumn{8}{|c|}{ Snowpack sublimation (mm) eastern subset E1 } \\
\hline & Oct & Nov & Dec & Jan & Feb & Mar & Apr & Sum \\
\hline JULES & 5.1 & 6.3 & 2.4 & 2.3 & 6.0 & 11.1 & 6.6 & 39.8 \\
\hline \multirow[t]{3}{*}{ SDGVM } & 1.5 & 1.3 & 0.7 & 0.7 & 1.1 & 2.5 & 4.0 & 11.8 \\
\hline & \multicolumn{8}{|c|}{ Snowpack sublimation $(\mathrm{mm})$ western subset W1 } \\
\hline & Oct & Nov & Dec & Jan & Feb & Mar & Apr & Sum \\
\hline JULES & 1.9 & 6.0 & 6.6 & 6.7 & 10.1 & 14.5 & 1.9 & 47.7 \\
\hline SDGVM & 0.2 & 0.9 & 1.0 & 1.0 & 1.4 & 2.7 & 2.7 & 9.9 \\
\hline
\end{tabular}

west (loss of snow) driven by sublimation, especially during the latter part of the snow season, and (ii) a positive but smaller magnitude of seasonal $A_{S}$ in the east, arising from the combined effect of condensation during winter and sublimation in spring, caused by different meteorological conditions and vegetation cover. Although the retrieved values of $A_{\mathrm{S}}$ are temporally and spatially restricted, they show (Table 1) lower values for forest cover than field, an overall lower value in the eastern subset than in the west for the months examined, and condensation for forest cover in eastern Siberia during February. This is consistent with our findings.

Table 2 gives the monthly snowpack sublimation values for subsets E1 and W1 as produced by JULES and SDGVM (LPJ-WM does not consider sublimation and CLM4CN does not include it in its standard list of outputs). Neither of the models considers snow divergence or sublimation of blowing snow, so sublimation is the only process contributing to $A_{\mathrm{S}}$. JULES correctly captures the increased sublimation in the west compared to the east, which is caused by the differences in field cover and relative air humidity mentioned earlier. For subset $\mathrm{E} 1$ the seasonal $A_{\mathrm{S}}$ is $39.8 \mathrm{~mm}$, while for $\mathrm{W} 1$ it is $47.7 \mathrm{~mm}$. In the west, this is consistent with the value of 50-75 mm from the modelling approach of Dery and Yau (2002), but not in the eastern sector, where they give a value of 5-25 mm. This overestimate by JULES seems to be caused by the fact that no individual months in JULES have overall deposition in E1, while deposition does occur in the models by Brun et al. (2013) and Yang et al. (2010) and is also found in our estimated values of $A_{S}$. SDGVM disagrees with all other approaches, underestimating the seasonal values of $A_{\mathrm{S}}$ and giving higher values for E1 than $\mathrm{W} 1$ (11.8 mm and $9.9 \mathrm{~mm}$ respectively). The optimization in Sect. 5.2 explains how these shortcomings of SDGVM can be partly alleviated.

\section{Discussion}

From an Earth-system perspective, these results prompt the question of how an inaccurate description of the snow regime in a land surface model can affect other elements of the land 
surface system it is attempting to simulate. Despite the relatively long snow season found at these latitudes, climate data, such as CRU TS 3.0, show that the bulk of precipitation occurs during the spring and summer months. Even though inaccuracies in the models would affect runoff during the melting season, this will have little impact on the overall water balance, which is mostly affected by the spring and summer rainfalls and evapotranspiration during those months. During winter, though, the snowpack acts as a thermal buffer whose depth and density affect heat transfer between the atmosphere and soil; an inaccurate description of the snow regime can therefore affect simulations of soil temperature and permafrost extent. As land surface models start to include permafrost parameterizations, it is essential to understand the magnitude and nature of the complications that could arise if the defects in simulating snow processes described earlier are not resolved.

To investigate how large these effects could be, the atmosphere-snowpack-soil heat exchange formulation of LPJ-WM, the only one of our models that includes organic soils and a complete permafrost parameterization, was forced with snow variables acquired from the field data using the methodology detailed in Sect. 3.3. It has already been shown that (a) soil temperatures simulated by LPJ-WM compare favourably overall with a limited set of field measurements across the boreal region (Wania et al., 2009b) and (b) simulated permafrost temperatures are in agreement with a large ground data set over Siberia (Kantzas, 2012). In this section we therefore focus on the implications of process representation errors, and in particular on how inaccuracies in simulated snow metrics can lead to errors in soil temperatures and soil carbon decomposition.

\subsection{Driving LPJ-WM with snow-related field measurements}

The 30-year time span and 5- to 10-day temporal spacing of the field records provide sufficient data on snow variables, such as depth and density, to force the heat diffusion formulation of LPJ-WM. Furthermore, since it treats snow density as constant except in the last quarter of the snow season, comparison of model calculations with and without imposing observed values of snow density offers insight into the consequences of using a simplified snow density evolution.

We calculated differences between modelled and field values of snow depth and density for several field stations; three representative examples are shown in Fig. 5, together with values of soil temperature at $25 \mathrm{~cm}$ depth estimated by the model in its unmodified form, and when driven by observed snow depth alone (LPJ-WM S) and by both depth and density (LPJ-WM SD). As expected, where LPJ-WM overestimates snow depth, modelled soil temperatures are lower in winter, when the model is forced by observed snow depth. This is illustrated by Fig. 5 (top) for the Njuja station in eastern Siberia in a region of continuous permafrost. Here the soil temperatures exhibited an average decrease of $6{ }^{\circ} \mathrm{C}$ at $25 \mathrm{~cm}$ depth during January for the period 1966-1996 when using observed snow depth. However, there was little difference in soil temperature for the upper soil layers during the late spring and summer months, and the summer thaw depth was unaffected. As a consequence, the integrated annual heterotrophic respiration decreased by approximately $7.4 \%$; this was the largest change out of the nine stations examined, since the biggest difference in snow depth between LPJ-WM and field data was at Njuja.

The Tevriz station is located in central Siberia and here LPJ-WM places the permafrost boundary at a depth just below $25 \mathrm{~cm}$ (Fig. 5, middle). There is less consistency between modelled and observed snow depth than at Njuja, with good agreement in some years but overestimates in others. The soil response is also less consistent: significant overestimates of snow depth do not always yield reduced winter temperatures (for example, in 1983 or 1984). In fact, for those particular years, even though field data indicated less snow than the model, they also showed an earlier start to the snow season, which compensated for the reduced snow depth later in the snow season and prevented lower soil temperatures. Although temperature differences up to $5^{\circ} \mathrm{C}$ are observed for January in 1980 and 1981, the summer temperature shows only a small decrease, so again the thaw depth is unaffected, while heterotrophic respiration reduces by $7.3 \%$.

At Olekminsk station in eastern Siberia, the magnitude and timing of snow depth are very similar in LPJ-WM and field data (Fig. 5, bottom), so forcing the model with field data has little effect on the simulated soil temperatures, and causes integrated annual heterotrophic respiration to reduce by only $1.3 \%$. Additionally, as for the other two stations, it was found that forcing the model with snow density as well as snow depth made little difference to soil temperatures. Hence simulations of soil temperature and consequently soil carbon decomposition in LPJ-WM are sensitive to inaccuracies in both snow magnitude (Fig. 2, right) and timing (Fig. 2, left) but are insensitive to snow density, so the assumption of a quasiconstant snow density used in LPJ-WM is not a significant source of uncertainty.

\subsection{Optimization of the SDGVM model}

Section 4 revealed the various shortcomings of each model in capturing the snow dynamics, and Sect. 5.1 demonstrated that, at least for LPJ-WM, there can be important consequences for simulating soil carbon fluxes. Hence we developed an optimization method which employs the available field records of SWE to improve model snow parameterization and snow simulations. The approach used is modelindependent, but is described with respect to the SDGVM, since this is the fastest-running model in our model suite due to its relatively large time step (daily instead of hourly) and simple process descriptions. Monthly averages of SWE were produced from the transect data, which contain 1345 

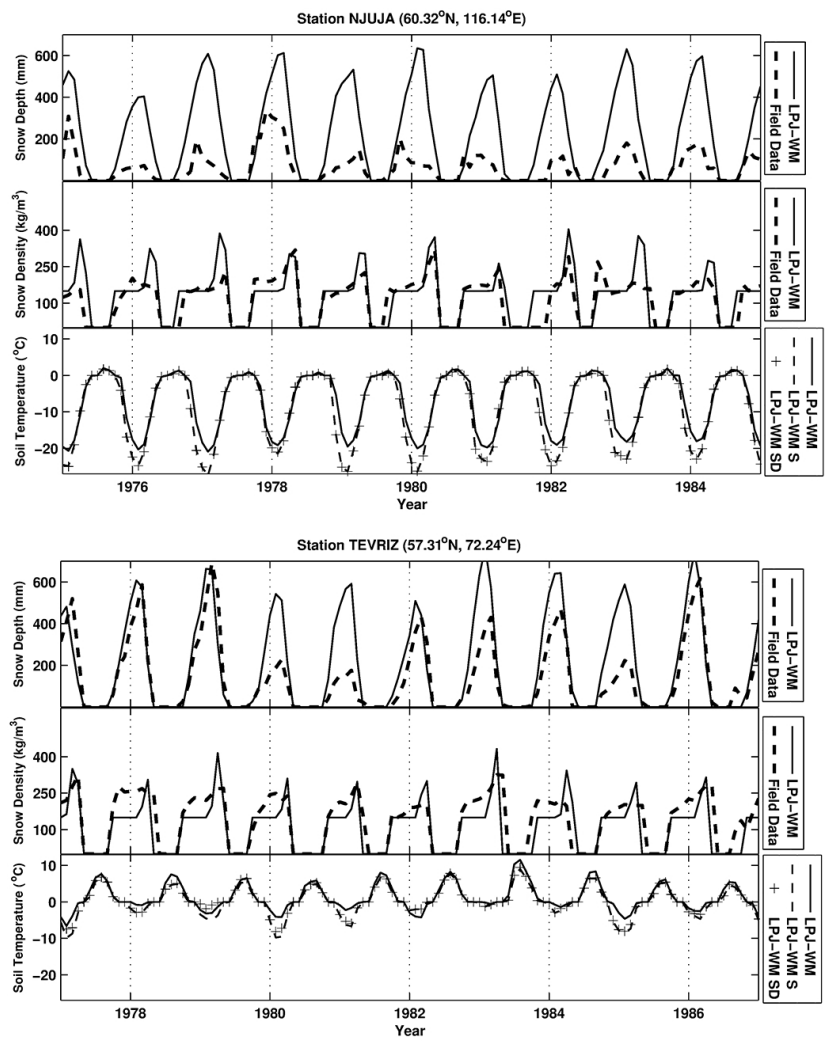

Station OLEKMINSK $\left(60.24^{\circ} \mathrm{N}, 120.25^{\circ} \mathrm{E}\right)$

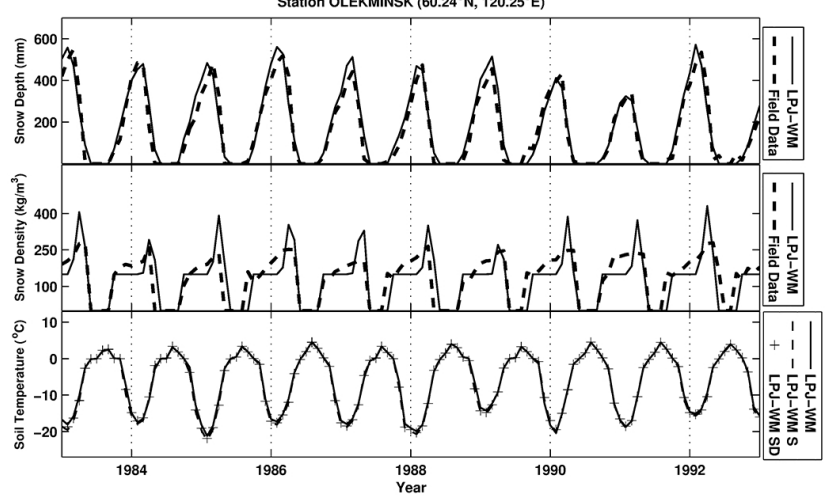

Fig. 5. Comparisons of snow depth $(\mathrm{mm})$ and snow density $\left(\mathrm{kg} \mathrm{m}^{-3}\right)$ acquired from LPJ-WM simulations and field data for three WMO stations located in eastern and central Siberia. The bottom subplot in each figure shows the monthly soil temperature $\left({ }^{\circ} \mathrm{C}\right)$ at a depth of $25 \mathrm{~cm}$ produced by LPJ-WM, along with the corresponding temperature when the model is driven by snow depth alone (LPJ-WM S) and with both snow depth and density (LPJ-WM SD) using values taken from the field records.

sites. The optimization process finds the parameter set giving the minimum average absolute monthly difference in snow months between observation and model, averaged over all sites, where a snow month is defined as any month having a positive value of SWE in either the observations or the model. It employs the "downhill simplex method in multidimensions" (Press et al., 1992), modified to allow sensible
Table 3. Original and optimized parameters of the SDGVM model: snow start temperature limit $\left({ }^{\circ} \mathrm{C}\right)$, snow melt temperature limit $\left({ }^{\circ} \mathrm{C}\right)$, snow melt rate and sublimation rate.

\begin{tabular}{lrr}
\hline Parameter & SDGVM & SDGVM-Opt \\
\hline Snow start temperature limit & $0{ }^{\circ} \mathrm{C}$ & $-4.38^{\circ} \mathrm{C}$ \\
Snow melt temperature limit & $0{ }^{\circ} \mathrm{C}$ & $0.61^{\circ} \mathrm{C}$ \\
Snow melt rate & 1 & 0.31 \\
Sublimation rate & 1 & 3.79 \\
\hline
\end{tabular}

physical constraints to be applied to the parameters being optimized. Although slow, this algorithm does not rely on estimates of gradients, so is robust against non-differentiability, which can occur, for example, if one of the parameters being optimized is a threshold on a model process.

The optimization was over the four parameters playing a major role in the timings and dynamics of the snowpack:

1. the average daily temperature at which snow occurs, which determines the start date of the snowpack and is set to $0{ }^{\circ} \mathrm{C}$ in SDGVM;

2. the average daily temperature at which snow melts, which affects the end date of the snowpack and is also set to $0{ }^{\circ} \mathrm{C}$;

3. the rate at which snow melts, which is proportional to temperature and affects the end date of the snowpack;

4. the sublimation rate, which is proportional to potential evapotranspiration and affects the overall size of the snowpack

The system is biased towards western Europe, where there is a high concentration of observational sites (Fig. 1). This has been countered to some extent by selecting only one site per $2^{\circ}$ square of latitude and longitude for the optimization, and using the one with most observations if there are multiple sites in such a square.

\subsubsection{Optimization results}

After the optimization, the average absolute error in monthly SWE between SDGVM and transect measurements reduced from 33.9 to $28.3 \mathrm{~mm}$, largely because of reduced SWE in the western sector; the correlation between SDGVM and transect data also improved a little, with $77 \%$ of grid cells having $\rho \geq 0.6$, from the original value of $74 \%$ (see Sect. 4.1). The optimized parameters are given in Table 3; there are large differences in all parameters, but particularly the sublimation rate and the temperature threshold for snow start.

The reduction in the snow start temperature threshold leads to a shorter snow season and less snow over the year for all sites. The increase in the sublimation rate by a factor of almost 4 also reduces SWE, and indicates that SDGVM underestimates sublimation, in agreement with the findings of 
Sect. 4.4. Both changes reduce the overestimation of SWE by the model and improve its description of the snow dynamics in the west.

A similar approach could be applied to any of the models in order to identify weaknesses in their snow process descriptions and inaccuracies in associated parameters. However, a different philosophy was adopted by Brun et al. (2013), who assumed that model-data SWE discrepancies arose from inadequacies in the climate data. Employing the same field measurements, they therefore optimized the performance of the CROCUS snow model embedded in the ISBA model (Noilhan and Mahfouf, 1996) by varying the climate drivers while keeping the model parameters constant, and assessed performance in terms of best-fit statistics between simulated and measured snow variables. Both methods could be used independently or in tandem to optimize snow simulations in a land surface model.

\section{Conclusions}

The first part of this study makes extensive use of field transect measurements to evaluate how well a range of Earth observation data sets and land surface models perform in describing snow dynamics across the extent of the FSU. The following was found:

- GlobSnow offers an accurate SWE product which, due to its global coverage, resolution and 30-year time span, is invaluable for benchmarking SWE retrievals in land surface models when field data are insufficient, and allows for identification of regions where improvement is needed.

- All the models reproduce the seasonal dynamics of SWE in Eurasia, although for LPJ-WM, SDGVM and CLM4CN there are model-specific regions where there are systematic and significant anomalies, particularly in the western sector, where none of these models captures the magnitude of SWE. Only JULES adequately captures the observed inter-annual variability, but systematically underestimates SWE throughout the region. Further work is required to identify the causes of these failures and their consequences for assigning uncertainty to trends in snow cover at high latitudes predicted by the models.

- A novel method for estimating early-season fresh snow density found it to have values in this region lying between 68 and $111 \mathrm{~kg} \mathrm{~m}^{-3}$. CLM4CN captures the snow density evolution, while JULES underestimates snow density throughout the season. In both cases, better model estimates of the magnitude of SWE may improve the simulated evolution of snow density.

- Our new approach to determining snowpack sublimation from the transect records yields values consis- tent with reported field observations and models, and shows that the process representation in JULES gives acceptable values of sublimation. The approach is being further exploited to produce a data set indicating the dynamics of sublimation across Eurasia, with specific emphasis on its inter-annual variability and trends, as well as its correlation with land cover and meteorological conditions.

Driving the atmosphere-snowpack-soil heat exchange formulation of LPJ-WM with snow metrics derived from field measurements revealed how inaccuracies in simulated snow properties can affect both heterotrophic respiration and the winter soil temperatures, although thaw depth remained unaffected. For locations where LPJ-WM overestimated SWE, winter soil temperatures in the model forced by data were much lower than those produced by the original model. This is consistent with a study by Dankers et al. (2011), which incorporated permafrost dynamics into JULES and gave significantly lower soil temperatures than were observed, especially in winter; this was attributed to inaccuracies in JULES SWE, as was found above for LPJ-WM. Improvements by Burke et al. (2013) reduced the cold bias observed by Dankers et al. (2011) but did not remove it; this was again attributed to underestimation of SWE. Dankers et al. (2011) used only a small set of field data around the Arctic, but the abundance of transect records across Eurasia offers the opportunity to investigate model underestimation of SWE and correct it using the optimization methods presented in this study. A similar approach could lead to improvements in simulated snow density, although our calculations with LPJ-WM suggest this will have little effect on soil temperatures.

Overall, this study demonstrates yet again the importance of systematic field measurements in evaluating and improving land surface models. From the FSU data set it was possible to assess how well SWE was reproduced by several wellknown land surface models, infer fresh snow density and snow density evolution, quantify the effects of uncertainties in SWE on simulated soil temperatures, and test modelled values of snowpack sublimation. This melding of data with models should continually inform efforts to improve models, and is essential if the efficacy of adding new processes is to be properly assessed. As an example, the effect of adding a permafrost formulation to JULES could not be properly tested against observed soil temperature because the simulated SWE is significantly underestimated. This highlights the need for better integration of detailed and accurate data sets (in situ or EO) into the community of land surface models if we are to reduce the large uncertainties in the predictions from these models.

Acknowledgements. This study was supported by the EU FP7 project Monarch-A (grant no. 242446), Monitoring and assessing regional climate change in high latitudes and the Arctic, and the EU FP7 project EuRuCAS (grant no. 295068), European-Russian 
Centre for cooperation in the Arctic and sub-Arctic environmental and climate research.

Edited by: M. Petters

\section{References}

Anderson, E. A.: A point energy and mass balance model for snow cover, Technical Report Nws 19, in: NOAA, Office of Hydrology, National Weather Service, Silver Spring, MD, 1976.

Bartlett, P. A., MacKay, M. D., and Verseghy, D. L.: Modified snow algorithms in the canadian land surface scheme: Model runs and sensitivity analysis at three boreal forest stands, Atmos. Ocean, 44, 207-222, doi:10.3137/ao.440301, 2006.

Best, M.: Jules technical documentation, in: Met Office, Met Office, 2009.

Best, M. J., Pryor, M., Clark, D. B., Rooney, G. G., Essery, R .L. H., Ménard, C. B., Edwards, J. M., Hendry, M. A., Porson, A., Gedney, N., Mercado, L. M., Sitch, S., Blyth, E., Boucher, O., Cox, P. M., Grimmond, C. S. B., and Harding, R. J.: The Joint UK Land Environment Simulator (JULES), model description Part 1: Energy and water fluxes, Geosci. Model Dev., 4, 677-699, doi:10.5194/gmd-4-677-2011, 2011.

Bohren, C. F. and Beschta, R. L.: Snowpack albedo and snow density, Cold Reg. Sci. Technol., 1, 47-50, doi:10.1016/0165232x(79)90018-1, 1979.

Boone, A., Mognard, N., Decharme, B., Douville, H., Grippa, M., and Kerrigan, K.: The impact of simulated soil temperatures on the estimation of snow depth over siberia from ssm/i compared to a multi-model climatology, Remote Sens. Environ., 101, 482494, doi:10.1016/j.rse.2006.01.014, 2006.

Brun, E., Vionnet, V., Boone, A., Decharme, B., Peings, Y., Valette, R., Karbou, F., and Morin, S.: Simulation of northern eurasian local snow depth, mass, and density using a detailed snowpack model and meteorological reanalyses, J. Hydrometeorol., 14, 203-219, doi:10.1175/Jhm-D-12-012.1, 2013.

Bulygina, O. N., Groisman, P. Y., Razuvaev, V. N., and Korshunova, N. N.: Changes in snow cover characteristics over northern eurasia since 1966, Environ. Res. Lett., 6, 045204, doi:10.1088/17489326/6/4/045204, 2011.

Buligina, O. N., Razuvaev, V. N., and Aleksandrova, T. M.: Dataset of Routine snow surveys, All-Russian Research Institute of Hydrometeorological Information-World Data Center, Obninsk, Russia, 2013

Burke, E. J., Dankers, R., Jones, C. D., and Wiltshire, A. J.: A retrospective analysis of pan arctic permafrost using the jules land surface model, Clim. Dynam., 41, 1025-1038, doi:10.1007/s00382012-1648-x, 2013.

Christensen, J. H., Hewitson, B., Busuioc, A., Chen, A., Gao, X., Held, I., Jones, R., and Kolli, R. K.: Regional climate projections, in: Climate change 2007: The physical science basis. Contribution of working group $i$ to the fourth assessment report of the intergovernmental panel on climate change edited by: Solomon, S., Qin, D., Manning, M., Chen, Z., Marquis, M., Averyt, K. B., Tignor, M., and Miller, H. L., Cambridge University Press, Cambridge, UK, 847-940, 2007.

Collins, W. D., Bitz, C. M., Blackmon, M. L., Bonan, G. B., Bretherton, C. S., Carton, J. A., Chang, P., Doney, S. C., Hack, J. J., Henderson, T. B., Kiehl, J. T., Large, W. G., McKenna, D. S.,
Santer, B. D., and Smith, R. D.: The community climate system model version 3 (ccsm3), J. Climate, 19, 2122-2143, 2006.

Cox, P. and Stephenson, D.: Climate change - a changing climate for prediction, Science, 317, 207-208, doi:10.1126/science.1145956, 2007.

Cramer, W., Bondeau, A., Woodward, F. I., Prentice, I. C., Betts, R. A., Brovkin, V., Cox, P. M., Fisher, V., Foley, J. A., Friend, A. D., Kucharik, C., Lomas, M. R., Ramankutty, N., Sitch, S., Smith, B., White, A., and Young-Molling, C.: Global response of terrestrial ecosystem structure and function to $\mathrm{CO}_{2}$ and Climate Change: Results from six dynamic global vegetation models, Glob Change Biol., 7, 357-373, 2001.

Dankers, R., Burke, E. J., and Price, J.: Simulation of permafrost and seasonal thaw depth in the JULES land surface scheme, The Cryosphere, 5, 773-790, doi:10.5194/tc-5-773-2011, 2011.

Davis, R. E., Hardy, J. P., Ni, W., Woodcock, C., McKenzie, J. C., Jordan, R., and Li, X.: Variation of snow cover ablation in the boreal forest: A sensitivity study on the effects of conifer canopy, J. Geophys. Res.-Atmos., 102, 29389-29395, 1997.

Derksen, C. and Brown, R.: Spring snow cover extent reductions in the 2008-2012 period exceeding climate model projections, Geophys. Res. Lett., 39, L19504, doi:10.1029/2012g1053387, 2012.

Dery, S. J. and Yau, M. K.: Large-scale mass balance effects of blowing snow and surface sublimation, J. Geophys. Res.-Atmos., 107, 4679, doi:10.1029/2001jd001251, 2002.

Essery, R. and Clark, D. B.: Developments in the moses 2 landsurface model for pilps 2e, Global Planet. Change, 38, 161-164, doi:10.1016/S0921-8181(03)00026-2, 2003.

Flanner, M. G., Zender, C. S., Randerson, J. T., and Rasch, P. J.: Present-day climate forcing and response from black carbon in snow, J. Geophys. Res.-Atmos., 112, D11202, doi:10.1029/2006jd008003, 2007.

Foster, J. L., Chang, A. T. C., and Hall, D. K.: Comparison of snow mass estimates from prototype passive microwave snow algorithm, a revised algorithm and a snow depth climatology, Remote Sens. Environ., 62, 132-142, 1997.

Friedlingstein, P., Cox, P., Betts, R., Bopp, L., Von Bloh, W., Brovkin, V., Cadule, P., Doney, S., Eby, M., Fung, I., Bala, G., John, J., Jones, C., Joos, F., Kato, T., Kawamiya, M., Knorr, W., Lindsay, K., Matthews, H. D., Raddatz, T., Rayner, P., Reick, C., Roeckner, E., Schnitzler, K. G., Schnur, R., Strassmann, K., Weaver, A. J., Yoshikawa, C., and Zeng, N.: Climate-carbon cycle feedback analysis: Results from the C(4)MIP Model Intercomparison, J. Climate, 19, 3337-3353, 2006.

GCOS: Implementation plan for the Global Observing System for Climate in Support of the UNFCCC, GCOS-92, WMO Technical Document no. 1219, Geneva, WMO, 2004.

GCOS: Implementation plan for the Global Observing System for Climate in Support of the UNFCCC (2010 update), WMO, 2010.

Gelfan, A. N., Pomeroy, J. W., and Kuchment, L. S.: Modeling forest cover influences on snow accumulation, sublimation, and melt, J. Hydrometeorol., 5, 785-803, doi:10.1175/15257541(2004)005<0785:Mfcios>2.0.Co;2, 2004.

Gerten, D., Schaphoff, S., Haberlandt, U., Lucht, W., and Sitch, S.: Terrestrial vegetation and water balance - hydrological evaluation of a dynamic global vegetation model, J. Hydrol., 286, 249270, doi:10.1016/j.jhydrol.2003.09.029, 2004. 
Gibson, J. K., Kallberg, P., Uppala, S., Hernandez, A., Nomura, A., and Serrano, E.: ERA Description: ECMWF Re-Analysis Project Report Series (ver. 2), European Centre for Medium Range Weather Forecasts, 84 pp., Reading, England, 1999.

Groisman, P. Y., Karl, T. R., and Knight, R. W.: Observed impact of snow cover on the heat-balance and the rise of continental spring temperatures, Science, 263, 198-200, doi:10.1126/science.263.5144.198, 1994.

Hancock, S., Baxter, R., Evans, J., and Huntley, B.: valuating global snow water equivalent products for testing land surface models, Remote Sens. Environ., 128, 107-117, doi:10.1016/j.rse.2012.10.004, 2013a.

Hancock, S., Huntley, B., Ellis, R., and Baxter, R.: Biases in reanalysis snowfall found by comparing the jules land surface model to globsnow, J. Climate, 27, 624-632, doi:10.1175/jclid-13-00382.1, 2013b.

Hansen, M. C., DeFries, R. S., Townshend, J. R. G., Carroll, M., Dimiceli, C., and Sohlberg, R. A.: Global percent tree cover at a spatial resolution of 500 meters: First results of the modis vegetation continuous fields algorithm, Earth Interact., 7, 1-15, doi:10.1175/1087-3562(2003)007<0001:GPTCAA>2.0.CO;2 , 2003.

Harding, R. J. and Pomeroy, J. W.: Energy balance of the winter boreal landscape, J. Climate, 9, 2778-2787, doi:10.1175/15200442(1996)009<2778:Tebotw>2.0.Co;2, 1996.

Harding, R. J. and Warnaars, T. A.: Water and global change: The watch project outreach report, Centre for Ecology and Hydrology, Wallingford, 40 pp., 2011

Hood, E., Williams, M., and Cline, D.: Sublimation from a seasonal snowpack at a continental, mid-latitude alpine site, Hydrol. Process., 13, 1781-1797, doi:10.1002/(Sici)10991085(199909)13:12/13<1781::Aid-Hyp860>3.0.Co;2-C, 1999.

Judson, A. and Doesken, N.: Density of freshly fallen snow in the central rocky mountains, B. Am. Meteorol. Soc., 81, 1577-1587, 2000.

Kalnay, E., Kanamitsu, M., Kistler, R., Collins, W., Deaven, D., Gandin, L., Iredell, M., Saha, S., White, G., Woollen, J., Zhu, Y., Chelliah, M., Ebisuzaki, W., Higgins, W., Janowiak, J., Mo, K. C., Ropelewski, C., Wang, J., Leetmaa, A., Reynolds, R., Jenne, R., and Joseph, D.: The NCEP/NCAR 40-year reanalysis project, B. Am. Meteorol. Soc., 77, 437-471, doi:10.1175/15200477(1996)077<0437:Tnyrp>2.0.Co;2, 1996.

Kanamitsu, M., Ebisuzaki, W., Woollen, J., Yang, S. K., Hnilo, J. J., Fiorino, M., and Potter, G. L.: NCEP-DOE AMIPII Reanalysis (R-2), B. Am. Meteorol. Soc., 83, 1631-1643, doi:10.1175/Bams-83-11-1631, 2002.

Kantzas, E.: Model for energy flows in permafrost/soil/snow/atmosphere layered media interfaced to the bcm climate model, EU FP7 MONARCH-A (Grant no. 242446), 2012.

Kouraev, A. V. and Mognard, N.: Monthly and 5-day fields of snow extent, start and end dates of snow cover, EU FP7 MONARCH-A (Grant no. 242446), 2010.

Krenke, A.: Former soviet union hydrological snow surveys, in: NSIDC, Boulder, CO, 2004.

Lawrence, D. M. and Slater, A. G.: Incorporating organic soil into a global climate model, Clim. Dynam., 30, 145-160, doi:10.1007/s00382-007-0278-1, 2008.
Lawrence, D. M., Slater, A. G., Romanovsky, V. E., and Nicolsky, D. J.: Sensitivity of a model projection of near-surface permafrost degradation to soil column depth and representation of soil organic matter, J. Geophys. Res.-Earth, 113, F02011, doi:10.1029/2007jf000883, 2008.

Lawrence, D. M., Oleson, K. W., Flanner, M. G., Thornton, P. E., Swenson, S. C., Lawrence, P. J., Zeng, X. B., Yang, Z. L., Levis, S., Sakaguchi, K., Bonan, G. B., and Slater, A. G.: Parameterization improvements and functional and structural advances in version 4 of the community land model, J. Adv. Model. Earth. Sy., 3, 2011MS000045, doi:10.1029/2011ms000045, 2011.

Le Quere, C., Raupach, M. R., Canadell, J. G., Marland, G., Bopp, L., Ciais, P., Conway, T. J., Doney, S. C., Feely, R. A., Foster, P., Friedlingstein, P., Gurney, K., Houghton, R. A., House, J. I., Huntingford, C., Levy, P. E., Lomas, M. R., Majkut, J., Metzl, N., Ometto, J. P., Peters, G. P., Prentice, I. C., Randerson, J. T., Running, S. W., Sarmiento, J. L., Schuster, U., Sitch, S., Takahashi, T., Viovy, N., van der Werf, G. R., and Woodward, F. I.: Trends in the sources and sinks of carbon dioxide, Nat. Geosci., 2, 831-836, doi:10.1038/Ngeo689, 2009.

Ling, F. and Zhang, T. J.: A numerical model for surface energy balance and thermal regime of the active layer and permafrost containing unfrozen water, Cold Reg. Sci. Technol., 38, 1-15, doi:10.1016/S0165-232x(03)00057-0, 2004.

Liston, G. E. and Elder, K.: A distributed snow-evolution modeling system (snowmodel), J. Hydrometeorol., 7, 1259-1276, doi:10.1175/Jhm548.1, 2006.

Lundberg, A. and Halldin, S.: Snow interception evaporation. Review of measurement techniques, processes, and models, Theor. Appl. Climatol., 70, 117-133, doi:10.1007/s007040170010, 2001.

Luojus, K., Pulliainen, J., Takala, M., Lemmetyinen, J., Kangwa, M., Smolander, T., Vehvilainen, J., Derksen, C., Metsamaki, S., and Bojkov, B.: Investigating snow accumulation on northern hemisphere using globsnow snow water equivalent data, Geophys. Res. Abstr., 13, EGU2011-7806-1, 2011.

McGuire, A. D., Melillo, J. M., Kicklighter, D. W., and Joyce, L. A.: Equilibrium responses of soil carbon to climate change: Empirical and process-based estimates, J. Biogeogr., 22, 785-796, 1995.

Mitchell, T. D. and Jones, P. D.: An improved method of constructing a database of monthly climate observations and associated high-resolution grids, Int. J. Climatol., 25, 693-712, doi:10.1002/Joc.1181, 2005.

Mognard, N. M. and Josberger, E. G.: Northern great plains 1996/97 seasonal evolution of snowpack parameters from satellite passive-microwave measurements, Ann. Glaciol., 34, 15-23, 2002.

Molotch, N. P., Blanken, P. D., Williams, M. W., Turnipseed, A. A., Monson, R. K., and Margulis, S. A.: Estimating sublimation of intercepted and sub-canopy snow using eddy covariance systems, Hydrol. Process., 21, 1567-1575, doi:10.1002/Hyp.6719, 2007.

NCDC: Global surface summary of data, Version 8, National Oceanic \& Atmospheric Administration, 2013.

Noilhan, J. and Mahfouf, J. F.: The isba land surface parameterisation scheme, Global Planet. Change, 13, 145-159, doi:10.1016/0921-8181(95)00043-7, 1996.

Oelke, C., Zhang, T. J., Serreze, M. C., and Armstrong, R. L.: Regional-scale modeling of soil freeze/thaw over the 
arctic drainage basin, J. Geophys. Res.-Atmos., 108, 4314, doi:10.1029/2002jd002722, 2003.

Osterkamp, T. E.: Characteristics of the recent warming of permafrost in alaska, J. Geophys. Res.-Earth, 112, F02s02, doi:10.1029/2006jf000578, 2007.

Perovich, D. K.: Light reflection and transmission by a temperate snow cover, J. Glaciol., 53, 201-210, doi:10.3189/172756507782202919, 2007.

Piao, S. L., Fang, J. Y., Ciais, P., Peylin, P., Huang, Y., Sitch, S., and Wang, T.: The carbon balance of terrestrial ecosystems in china, Nature, 458, 1009-1013, doi:10.1038/Nature07944, 2009.

Polyakov, I. V., Alekseev, G. V., Bekryaev, R. V., Bhatt, U., Colony, R. L., Johnson, M. A., Karklin, V. P., Makshtas, A. P., Walsh, D., and Yulin, A. V.: Observationally based assessment of polar amplification of global warming, Geophys Res Lett, 29, 1878, doi:10.1029/2001g1011111, 2002.

Pomeroy, J. W. and Essery, R. L. H.: Turbulent fluxes during blowing snow: Field tests of model sublimation predictions, Hydrol. Process., 13, 2963-2975, doi:10.1002/(sici)10991085(19991230)13:18<2963::aid-hyp11>3.0.co;2-9, 1999.

Pomeroy, J. W., Parviainen, J., Hedstrom, N., and Gray, D. M.: Coupled modelling of forest snow interception and sublimation, Hydrol. Process., 12, 2317-2337, doi:10.1002/(sici)10991085(199812)12:15<2317::aid-hyp799>3.0.co;2-x, 1998.

Press, W. H., Teukolsky, S. A., Vetterling, W. T., and Flannery, B. P.: Numerical recipes in fortran: The art of scientific computing, Cambridge University Press, Cambridge, 1992.

Pulliainen, J.: Mapping of snow water equivalent and snow depth in boreal and sub-arctic zones by assimilating space-borne microwave radiometer data and ground-based observations, Remote Sens. Environ., 101, 257-269, doi:10.1016/j.rse.2006.01.002, 2006.

Razuvaev, V. N., Apasova, E. G., and Martuganov, R. A.: Daily Temperature and Precipitation Data for 223 FormerUSSR Stations. ORNL/CDIAC-56, NDP-040, Carbon Dioxide Information Analysis Center, Oak Ridge National Laboratory, US Department of Energy, Oak Ridge, Tennessee, doi:10.3334/CDIAC/cli.ndp040, 2008.

Reba, M. L., Pomeroy, J., Marks, D., and Link, T. E.: Estimating surface sublimation losses from snowpacks in a mountain catchment using eddy covariance and turbulent transfer calculations, Hydrol. Process., 26, 3699-3711, doi:10.1002/Hyp.8372, 2012.

Roebber, P. J., Bruening, S. L., Schultz, D. M., and Cortinas, J. V.: Improving snowfall forecasting by diagnosing snow density, Weather Forecast., 18, 264-287, 2003.

Saito, K., Yamaguchi, S., Iwata, H., Harazono, Y., Kosugi, K., Lehning, M., and Shulski, M.: Climatic physical snowpack properties for large-scale modeling examined by observations and a physical model, Polar Science, 6, 79-95, 2012.

Serreze, M. C. and Francis, J. A.: The arctic amplification debate, Clim. Change, 76, 241-264, doi:10.1007/s10584-005-9017-y, 2006.

Serreze, M. C., Walsh, J. E., Chapin, F. S., Osterkamp, T., Dyurgerov, M., Romanovsky, V., Oechel, W. C., Morison, J., Zhang, T., and Barry, R. G.: Observational evidence of recent change in the northern high-latitude environment, Clim. Change, 46, 159-207, doi:10.1023/A:1005504031923, 2000.
Stroeve, J., Holland, M. M., Meier, W., Scambos, T., and Serreze, M.: Arctic sea ice decline: Faster than forecast, Geophys Res Lett, 34, L09501, doi:10.1029/2007gl029703, 2007.

Stroeve, J. C., Serreze, M. C., Holland, M. M., Kay, J. E., Malanik, J., and Barrett, A. P.: The arctic's rapidly shrinking sea ice cover: A research synthesis, Clim. Change, 110, 1005-1027, doi:10.1007/s10584-011-0101-1, 2012.

Sturm, M.: Snow distribution and heat-flow in the taiga, Arctic Alpine Res., 24, 145-152, 1992.

Sturm, M., Holmgren, J., Konig, M., and Morris, K.: The thermal conductivity of seasonal snow, J. Glaciol., 43, 26-41, 1997.

Sturm, M., Racine, C., and Tape, K.: Climate change - increasing shrub abundance in the arctic, Nature, 411, 546-547, doi:10.1038/35079180, 2001.

Takala, M., Luojus, K., Pulliainen, J., Derksen, C., Lemmetyinen, J., Karna, J. P., Koskinen, J., and Bojkov, B.: Estimating northern hemisphere snow water equivalent for climate research through assimilation of space-borne radiometer data and groundbased measurements, Remote Sens. Environ., 115, 3517-3529, doi:10.1016/j.rse.2011.08.014, 2011.

Tarnocai, C., Canadell, J. G., Schuur, E. A. G., Kuhry, P., Mazhitova, G., and Zimov, S.: Soil organic carbon pools in the northern circumpolar permafrost region, Global Biogeochem. Cy., 23, GB2023, doi:10.1029/2008gb003327, 2009.

Vernekar, A. D., Zhou, J., and Shukla, J.: The effect of eurasian snow cover on the indian monsoon, J. Climate, 8, 248266, doi:10.1175/1520-0442(1995)008<0248:Teoesc >2.0.Co;2, 1995.

Verseghy, D. L., Mcfarlane, N. A., and Lazare, M.: Class - a canadian land-surface scheme for GCMS. 2. Vegetation model and coupled runs, Int. J. Climatol., 13, 347-370, 1993.

Wania, R., Ross, I., and Prentice, I. C.: Integrating peatlands and permafrost into a dynamic global vegetation model: 1. Evaluation and sensitivity of physical land surface processes, Global Biogeochem. Cy., 23, GB3014, doi:10.1029/2008gb003412, 2009a.

Wania, R., Ross, I., and Prentice, I. C.: Integrating peatlands and permafrost into a dynamic global vegetation model: 2. Evaluation and sensitivity of vegetation and carbon cycle processes, Global Biogeochem Cy, 23, Gb3015, doi:10.1029/2008gb003413, 2009b.

Woodward, F. I., Smith, T. M., and Emanuel, W. R.: A global land primary productivity and phytogeography model, Global Biogeochem. Cy., 9, 471-490, 1995.

Woodward, F. I. and Lomas, M. R.: Vegetation dynamics - simulating responses to climatic change, Biol. Rev., 79, 643-670, doi:10.1017/S1464793103006419, 2004.

Yang, J., Yau, M. K., Fang, X., and Pomeroy, J. W.: A triplemoment blowing snow-atmospheric model and its application in computing the seasonal wintertime snow mass budget, Hydrol. Earth Syst. Sci., 14, 1063-1079, doi:10.5194/hess-14-10632010, 2010.

Zhang, Y. S., Suzuki, K., Kadota, T., and Ohata, T.: Sublimation from snow surface in southern mountain taiga of eastern Siberia, J. Geophys. Res.-Atmos., 110, D08109, doi:10.1029/2005jd005902, 2005. 